\title{
Homocystinuria: Heterozygote Detection using Phytohemagglutinin-Stimulated Lymphocytes
}

\author{
Joseph L. Goldstein, Barbara K. Campbell, and Stanley M. Gartler \\ From the Departments of Medicine and Genetics, University of Washington, \\ Seattle, Washington 98195
}

\begin{abstract}
A B S T R A C T Deficiency of cystathionine synthase activity results in the clinical syndrome of homocystinuria. Using phytohemagglutinin (PHA)-stimulated lymphocytes as a readily available source of this enzyme, its activity has been compared in 48 control subjects, seven homozygotes affected with homocystinuria, and 17 obligate heterozygotes. PHA-induced enzyme levels were highest in controls (mean $\pm S E M, 666.9 \pm 70.2$ pmol cystathionine formed/mg protein per $4 \mathrm{~h}$ ), intermediate in heterozygotes $(114.4 \pm 27.3)$, and absent to severely deficient in homozygotes (2.0 \pm 1.6$)$. Since only three of the 17 values from the obligate heterozygotes overlapped into the control range, this simple method may become clinically useful for heterozygote detection of carriers of the gene for abnormal cystathionine synthase. In addition, this system for induction of cystathionine synthase in lymphocytes has a more general relevance to human biochemical genetics in that it demonstrates that the absence of an enzyme in a normal cell does not preclude using that source for diagnosis of genetic disease if the enzyme can be induced.
\end{abstract}

\section{INTRODUCTION}

Homocystinuria is an inborn error of metabolism characterized clinically by the syndrome of mental retardation, dislocation of the lens, premature coronary artery and other vascular disease, and osteoporosis $(1,2)$. This disorder is inherited as an autosomal recessive trait (1), and the biochemical abnormality is due to a deficiency of cystathionine synthase (E. C. 4.2.1.21), the enzyme in the mammalian transsulfuration pathway

Dr. Goldstein's present address is the Division of Medical Genetics, Department of Internal Medicine, University of Texas Southwestern Medical School, Dallas, Tex.

Received for publication 5 September 1972 and in revised form 31 October 1972. which catalyzes the condensation of homocysteine and serine to cystathionine (3).

Homozygotes with homocystinuria are generally diagnosed by quantitative measurement of the levels of homocystine in urine and of methionine and homocystine in plasma (1), but may be more specifically diagnosed by demonstrating deficient cystathionine synthase activity in extracts from either liver biopsy (4) or cultured skin fibroblasts (5). Up to now, heterozygote detection has also been attempted by measurement of cystathionine synthase activity in extracts from liver $(4,6,7)$ and cultured fibroblasts (6). In the few obligate heterozygotes in whom enzyme activity has been measured, it averaged less than $50 \%$ of the levels found in controls $(4,6,7)$. Other attempts at heterozygote detection have been limited since cystathionine synthase activity has not been previously detectable in readily available tissues such as blood leukocytes, platelets, or red blood cells $(3,8)$.

We recently reported a simple method for inducing the activity of cystathionine synthase in normal human lymphocytes. This was accomplished by the addition of phytohemagglutinin (PHA) ${ }^{1}$ to short-term leukocyte cultures (9). This PHA-stimulated enzyme activity had characteristics that resembled those previously described for cystathionine synthase of normal human liver and cultured fibroblasts. It was completely dependent on the presence of homocysteine and was absent or severely deficient in extracts from individuals with the syndrome of homocystinuria.

In the present report we have utilized the PHAstimulated lymphocyte culture system to compare the activity of cystathionine synthase in control subjects, homozygotes with the clinical syndrome of homocystinuria, and obligate heterozygotes.

\footnotetext{
${ }^{1}$ Abbreviation used in this paper: PHA, phytohemagglutinin.
} 


\section{METHODS}

The 48 control subjects consisted of an equal number of consecutively studied men and women whose mean age was $33 \mathrm{yr}$ (range, 21-65). The seven homozygotes consisted of three male and four female subjects whose mean age was 20 yr (range, 5-40). The 17 obligate heterozygotes consisted of nine men and eight women who were either the parents $(n=16)$ or the offspring $(n=1)$ of individuals with the clinical syndrome of homocystinuria. Their mean age was $43 \mathrm{yr}$ (range, 15-60).

Each lymphocyte culture was initiated from $10 \mathrm{ml}$ of peripheral blood; this was obtained from each individual between the hours of 9 and 11 a.m. after a light breakfast. The blood was drawn into a heparinized (40 U.S.P. U heparin $/ \mathrm{ml}$ blood) plastic syringe and allowed to sediment at $37^{\circ} \mathrm{C}$ for $60-120 \mathrm{~min}$ until exactly $2 \mathrm{ml}$ of a plasma leukocyte suspension became available for inoculation into a sterile culture bottle. This was brought to a final volume of $24.5 \mathrm{ml}$ with minimal Eagle's media containing $10 \%$ fetal calf serum (North American Biologicals, Inc., Rockville, Md.), $50 \mathrm{mM} N$-tris (hydroxymethyl) methylglycine, $\mathrm{pH}$ 7.4, (Sigma Chemical Co., St. Louis, Mo.), penicillin $(100 \mu \mathrm{g} / \mathrm{ml})$, streptomycin $(100 \mu \mathrm{g} / \mathrm{ml})$, and $0.5 \mathrm{ml}$ of 1: 50 dilution of Phytohemagglutinin $P$ (Difco Laboratories, Detroit, Mich.). Each culture was incubated at $37^{\circ} \mathrm{C}$ and left undisturbed for $96 \mathrm{~h}$ at which time it was mixed well and then split into three parts: $23 \mathrm{ml}$ was used for preparation of the lymphocyte extract for measurement of cystathionine synthase activity, $1 \mathrm{ml}$ was used for measurement of thymidine incorporation into DNA, and $0.5 \mathrm{ml}$ was used for preparation of an erythrocyte-free lymphocyte extract for measurement of protein concentration.

Cystathionine synthase activity was measured using an assay that was reported earlier (9). A lymphocyte extract was prepared from each culture as previously described (9) and $50 \mu 1(0.2-0.7 \mathrm{mg}$ protein) of this extract was used as the source of enzyme in an incubation reaction of $0.1 \mathrm{~m}$. final volume containing: Tris- $\mathrm{HCl}(\mathrm{pH} 8.3), 150 \mathrm{mM}$; EDTA, $2.5 \mathrm{mM}$; pyridoxal phosphate, $0.65 \mathrm{mM}$; cystathionine, $0.17 \mathrm{mM}$; homocysteine, $10 \mathrm{mM}$; and $\left[3-{ }^{14} \mathrm{C}\right]$ serine (Schwarz BioResearch Inc., Orangeburg, N. Y.), $6.6 \mathrm{nmol}$ containing $300-330 \times 10^{3} \mathrm{cpm}$. Each reaction was incubated at $37^{\circ} \mathrm{C}$ for $4 \mathrm{~h}$. Previous studies had indicated that under these assay conditions cystathionine formation was proportional to time up to $6 \mathrm{~h}$ and to protein concentration up to $1.0 \mathrm{mg}$. The radioactive cystathionine formed in each reaction was isolated and quantitated by a thin-layer chromatographic technique that has been previously described (9).
Thymidine incorporation into DNA was determined by $0.05 \mathrm{ml}$ addition of $3 \mu \mathrm{Ci}$ of $\left[\right.$ methyl ${ }^{3} \mathrm{H}$ ] thymidine, specific activity $11.4 \mathrm{Ci} / \mathrm{mm}$, to a $1 \mathrm{ml}$ suspension of cultured $1 \mathrm{ym}$ phocytes, followed by incubation at $37^{\circ} \mathrm{C}$ for $60 \mathrm{~min}$. The reaction was stopped by the addition of $1 \mathrm{ml}$ of cold $10 \%$ TCA and the resulting precipitate was collected on a Millipore filter that was washed first with $15 \mathrm{ml}$ of cold $5 \%$ TCA followed by $5 \mathrm{ml}$ of ethanol. Each filter was dried, placed into a counting vial to which $5 \mathrm{ml}$ of $0.4 \%$ solution of 2, 5-diphenyloxazole (PPO) in toluene were added. The samples were assessed for radioactivity in a liquid scintillation counter in which the efficiency for ${ }^{3} \mathrm{H}$ averaged $38 \%$. The amount of thymidine incorporated to DNA was quantitated by subtracting a blank value which was equivalent to the zero time values $(0.01 \mathrm{pmol})$.

An erythrocyte-free lymphocyte extract for measurement of protein concentration was prepared by centrifugation of the cell suspensions at $1,000 \mathrm{rpm}$ for $10 \mathrm{~min}$. The resulting pellet was resuspended in $0.5 \mathrm{ml}$ of $0.9 \% \mathrm{NaCl}$ after which was added $2 \mathrm{ml}$ of $0.83 \% \mathrm{NH}_{4} \mathrm{Cl}$. After remaining at room temperature for $3 \mathrm{~min}$, this suspension of cells was recentrifuged at $1,000 \mathrm{rpm}$ for $10 \mathrm{~min}$. The resulting supernatant was discarded and the pellet, after being resuspended in $0.1 \mathrm{ml}$ of $\mathrm{H}_{2} \mathrm{O}$, was used for determination of protein concentration by the method of Lowry, Rosebrough, Farr, and Randall (10).

\section{RESULTS}

Table I compares the cystathionine synthase activity of the 48 control subjects, the 17 obligate heterozygotes, and the seven homozygotes with homocystinuria. Enzyme activity was highest in the controls, intermediate in the obligate heterozygotes and was detectable in only one of the seven homozygotes. The separation between the three phenotypes was highly significant regardless of whether enzyme activity was expressed in terms of the total activity per culture, the activity per milligram of soluble protein, or the activity per amount of thymidine incorporated into DNA. Since the rate of incorporation of thymidine into DNA did not differ significantly among controls (mean \pm SEM, 39.8 \pm 2.7

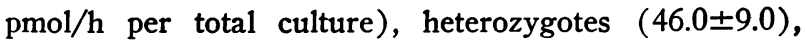
and homozygotes $(55.7 \pm 6.2)$, the difference in cystathionine synthase activity among these three groups could

TABLE I

Cystathionine Synthase Activity (Mean $\pm S E M$ ) in Controls, Heterozygotes, and Homozygotes

\begin{tabular}{|c|c|c|c|}
\hline \multirow{2}{*}{$\begin{array}{l}\text { Phenotype } \\
\text { (No. tested) }\end{array}$} & \multicolumn{3}{|c|}{ Cystathionine formed per $4 \mathrm{~h}$} \\
\hline & pmol/total culture & pmol/mg protein & pmol/pmol thymidine incorporated inlo DNA \\
\hline Controls (48) & $834.9 \pm 54.8$ & $666.9 \pm 70.2$ & $26.1 \pm 2.7$ \\
\hline & $P<0.001$ & $P<0.001$ & $P<0.001$ \\
\hline Heterozygotes (17) & $\begin{array}{r}219.5 \pm 50.3 \\
P<0.001\end{array}$ & $\begin{array}{r}114.4 \pm 27.3 \\
P<0.001\end{array}$ & $\begin{array}{r}6.0 \pm 1.0 \\
P<0.001\end{array}$ \\
\hline Homozygotes (7) & $6.8 \pm 6.0$ & $2.0 \pm 1.6$ & $0.3 \pm 0.3$ \\
\hline
\end{tabular}

Each reaction was incubated for $4 \mathrm{~h}$ at $37^{\circ} \mathrm{C}$ and contained in $0.1 \mathrm{ml}$ : lymphocyte extract (protein concentration varied between 0.2 and $0.7 \mathrm{mg}$ ) and additional components described in the text. The number in parentheses refers to the number of individuals studied in each phenotypic category. $(1 \mathrm{pmol}=50 \mathrm{cpm})$. 


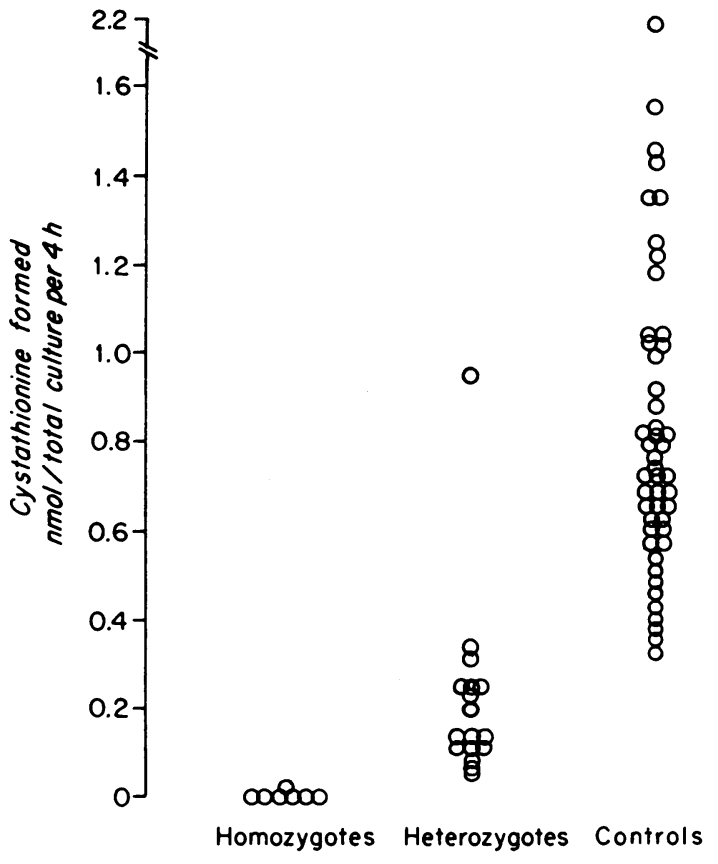

FIgURE 1 Distribution of the levels of cystathionine synthase activity among homozygotes, heterozygotes, and controls. Each reaction was incubated for $4 \mathrm{~h}$ at $37^{\circ} \mathrm{C}$ and contained in $0.1 \mathrm{ml}$ : lymphocyte extract (protein concentration varied between 0.2 and $0.7 \mathrm{mg}$ ) and additional components described in Methods. Enzyme activity is expressed as nanomole cystathionine formed per total culture per $4 \mathrm{~h}$. (1 $\mathrm{nmol}=50,000 \mathrm{cpm}$ )

not be explained on the basis of a difference in the PHA-responsiveness of their lymphocytes. Moreover, the $10 \mathrm{yr}$ difference in mean age between controls and the obligate heterozygotes was an unlikely explanation for their differences in cystathionine synthase activity since the activity of this enzyme did not vary significantly with age among controls $(r=-0.003)$.

Fig. 1 shows the distribution of the individual values of cystathionine synthase activity as determined for controls, heterozygotes, and homozygotes. Although most of the values of controls and heterozygotes segregated into two distinct populations, there were several examples of overlap. The reason for the large degree of variation in control values is not known, but may be related to the requirement for enzyme induction. The two lowest control values overlapping into the heterozygote range might in fact indicate that these two individuals are heterozygotes, since the frequency of heterozygotes in the general population could be as high as one in 50 to one in 100 (11). The one heterozygote whose value clearly fell into the normal range as shown in Fig. 1 is of special interest since she is the mother of three children with the classic clinical syndrome of homo- cystinuria ${ }^{2}$ and is by definition an obligate heterozygote. Her husband's value, $120 \mathrm{pmol} /$ total culture per $4 \mathrm{~h}$, clearly fell into the heterozygote range. When her enzyme activity was expressed in terms of cystathionine formed per milligram of soluble protein (449.5), it also fell into the normal range; but when expressed as cystathionine formed per amount of thymidine incorporated into DNA (10.6), it more closely resembled the heterozygote values.

\section{DISCUSSION}

The data presented in this study demonstrate that obligate heterozygotes for homocystinuria show a mean level of cystathionine synthase in PHA-stimulated lymphocytes significantly below that of control subjects. The observation that mean enzyme activity of heterozygotes was about $20 \%$ that of controls is in general agreement with previous heterozygote data in which the cystathionine synthase activity in extracts of liver and cultured fibroblasts averaged less than $40 \%$ of the control activity $(4,6,7)$. It is of interest that these observations do not follow the general rule in inborn errors of metabolism that average levels of enzyme activity in heterozygotes are usually about $50 \%$ of those found in normal subjects, consistent with a simple gene doasge relationship (12). The only other known exception in which the average level of heterozygote activity is smaller than would be expected from a simple gene dosage effect occurs in hereditary orotic aciduria (12); the mechanism for this effect in orotic aciduria is not known. It is possible that the lack of a simple gene dosage relationship in the cystathionine synthase activity of cultured lymphocytes may be related to the fact that the system is complicated by the requirement for enzyme induction.

That values from three of the 17 obligate heterozygotes tested in this study overlapped the control range must be taken into consideration if this technique is applied clinically in heterozygote detection. The reason for this overlap is not altogether clear but may be due to one of several factors: $(a)$ the presence of one or two unrecognized heterozygotes among the 48 control subjects and $(b)$ the metabolic complexities associated with PHA-induction of lymphocytes.

However, with further refinements in methodology, it should be possible to use this cultured lymphocyte system for direct determination of the heterozygote frequency of homocystinuria in the general population. Detection of carriers of the gene(s) for cystathionine synthase deficiency will not only be helpful in special genetic

\footnotetext{
${ }^{2}$ None of these three homocystinuric children has been proven to be cystathionine synthase deficient by means of enzyme assay.
} 
counseling situations that may arise in certain families, but may also have broader applications to clinical medicine and to the genetics of common disorders of adults. For example, it is well known that individuals with the clinical syndrome of homocystinuria who carry a double dose of the abnormal gene for cystathionine synthase are predisposed at young ages to the development of accelerated atherosclerosis which manifests in the form of myocardial infarction, cerebrovascular thrombosis, and peripheral vascular disease $(2,13)$. If a single dose of this gene were also to influence the atherosclerotic process, then the heterozygotes for cystathionine synthase deficiency, who occur at a relatively high frequency in the population, would show an enhanced predisposition to the development of a variety of different vascular diseases. Screening for heterozygotes among patients showing signs of premature atherosclerosis will now make it possible to test the validity of such an hypothesis.

In addition to providing a specific method for detection of heterozygotes for homocystinuria, the present studies, when considered together with our previous data on PHA-induction of cystathionine synthase activity in normal lymphocytes, may have more general relevance to human genetics. These data demonstrate that the absence of an enzyme in a normal cell does not preclude using that source for diagnosis of genetic disease if the enzyme can be induced (9). Thus, this PHA system may have wide applicability for detection of heterozygotes and homozygotes of other heritable disorders of metabolism.

\section{ACKNOWLEDGMENTS}

The following physicians allowed us to study their patients: Dr. C. R. Scott, Seattle; Dr. Thomas Perry, Vancouver, B. C.; Dr. D. A. Applegarth, Vancouver, B. C.; Dr. E. E. McCoy, Edmonton, Alberta; and Dr. Patricia A. Baird, Vancouver, B. C.

This work was supported by U. S. Public Health Service Grant GM 15253. Dr. Goldstein was formerly a recipient of NIH Special Fellowship GM 4784-01 and is now a Research Career Development Awardee 1-K4-GM70, 277-01 from the National Institute of General Medical Sciences.

\section{REFERENCES}

1. Laster, L., G. L. Spaeth, S. H. Mudd, and J. D. Finklestein. 1965. Homocystinuria due to cystathionine synthase deficiency. Ann. Intern. Med. 63: 1117.

2. Schimke, R. N., V. A. McKusick, and R. G. Weilbaecher. 1967. Homocystinuria. In Amino Acid Metabolism and Genetic Variation. W. L. Nyhan, editor. McGraw-Hill Book Company, New York. 297.

3. Mudd, S. H., J. D. Finklestein, F. Irreverre, and L. Laster. 1964. Homocystinuria: an enzymatic defect. Science (Wash. D. C.). $143: 1443$.

4. Finklestein, J. D., S. H. Mudd, F. Irreverre, and L. Laster. 1964. Homocystinuria due to cystathionine synthetase deficiency: the mode of inheritance. Science (Wash. D. C.). $146: 785$.

5. Uhlendorf, B. W., and S. H. Mudd. 1968. Cystathionine synthase in tissue culture derived from human skin: enzymatic defect in homocystinuria. Science (Wash. D. C.). $160: 1007$.

6. Mudd, S. H. 1970. Errors of sulfur metabolism. In Symposium: Sulphur in Nutrition. O. H. Muth and J. E. Oldfield, editors. AVI Publishing Company, Westport, Conn. 222.

7. Gaull, G. E., and J. A. Sturman. 1971. Vitamin $B_{6}$ dependency in homocystinuria. Br. Med. J. 3: 532.

8. Manowitz, P., J. Racevskis, and D. G. Gilmour. 1970. A modified assay for cystathionine synthase. Clin. Chim. Acta. 28: 269.

9. Goldstein, J. L., B. K. Campbell, and S. M. Gartler. 1972. Cystathionine synthase activity in human lymphocytes: induction by phytohemagglutinin. J. Clin. Invest. $51: 1034$.

10. Lowry, C. H., N. J. Rosenbrough, A. C. Farr, and R. J. Randall. 1951. J. Biol. Chem. 193 : 265.

11. Gerritsen, T., and H. A. Waisman. 1972. Homocystinuria. In The Metabolic Basis of Inherited Disease. J. B. Stanbury, J. B. Wyngaarden, and D. S. Fredrickson, editors. McGraw-Hill Book Company, New York. 404.

12. Harris, H. 1970. The Principles of Human Biochemical Genetics. North-Holland Publishing Company, Amsterdam. 171.

13. McCully, K. S. 1969. Vascular pathology of homocystinemia: implications for the pathogenesis of arteriosclerosis. Am. J. Pathol. 56 : 111. 